ISSN 1392-3196 / e-ISSN 2335-8947

Zemdirbyste-Agriculture, vol. 107, No. 2 (2020), p. 113-122

DOI 10.13080/z-a.2020.107.015

\title{
The effect of Fusarium culmorum on yield and grain characteristics of winter wheat cultivars
}

\author{
Ivana POLIŠENSKÁ ${ }^{1}$, Kateřina VACULOVÁ ${ }^{1}$, Ondřej JIRSA ${ }^{1}$, \\ Irena SEDLÁČKOVÁ ${ }^{1}$, Jan FRYDRYCH ${ }^{2}$ \\ ${ }^{1}$ Agrotest Fyto, Ltd. \\ Havlíčkova 2787, 76701 Kroměříž, Czech Republic \\ E-mail: polisenska@vukrom.cz \\ ${ }^{2}$ OSEVA Development and Research Ltd. \\ Hamerská 698, 75654 Zubří, Czech Republic
}

\begin{abstract}
The response to Fusarium culmorum infection was studied in winter wheat (Triticum aestivum L.) cultivars differing in baking quality. Deoxynivalenol (DON) content, grain yield and characteristics: test weight, thousand kernel weight, falling number, crude protein content, sedimentation index, wet gluten content and gluten index, were evaluated in wheat grown in field trials, established within two distinct environments in three successive harvest years. There were significant differences in the level of DON content between the locations, harvest years and cultivars. Considering the entire data set from the whole trial, F. culmorum infection systematically influenced all the considered variables, except for wet gluten content, with significant interactions with other factors in most cases. Results of the experiment confirmed the multi-factorial nature of Fusarium head blight disease and emphasized the fact, that although currently there is no fully resistant winter wheat cultivar available, there are substantial differences in susceptibility among the currently grown ones. Because of the multi-factorial nature of Fusarium head blight disease, protection measures should rely on more factors as well. The choice of less susceptible cultivar should be one of them.
\end{abstract}

Key words: cereals, cultivar, grain quality, Fusarium head blight, mycotoxin.

\section{Introduction}

Fusarium head blight (FHB), caused by a complex of several Fusarium species, is a destructive fungal disease of wheat and other small grain cereals. The composition of the Fusarium pathogen complex occurring on cereal heads is variable and is influenced by many factors, such as weather conditions, location, cropping practices (especially preceding crop) and also by the cereal species. In general, FHB has been reported to be caused on small grain cereals mainly by $F$. avenaceum, $F$. culmorum, $F$. graminearum, $F$. poae, Microdochium nivale and M. majus (Becher et al., 2013; Steiner et al., 2017; Bilska et al., 2018), most of which can contaminate the cereals with mycotoxins. Due to the variability of Fusarium pathogens involved in FHB, there is broad variability in the mycotoxin spectrum and concentrations. Deoxynivalenol (DON) is one of the most prevalent mycotoxins encountered in grain fields. DON belongs to the type B trichothecenes and is mainly produced by $F$. graminearum and $F$. culmorum. The European Union (Commission Regulation (EC) No 1881/2006) has established maximum limits for Fusarium mycotoxins DON and zearalenone in foodstuffs, including cereals and cereal products (EC, 2006). There are different maximum limits for DON content in unprocessed durum wheat, oats and maize (1 $750 \mu \mathrm{g} \mathrm{kg}^{-1}$ ) and for the other unprocessed cereals, including common wheat and barley (1 $\left.250 \mu \mathrm{g} \mathrm{kg}^{-1}\right)$.

Although toxicological risk resulting from mycotoxin contamination is of primary concern, other negative consequences of FHB infection include loss of grain yield and impaired technological quality. Two reasons for yield depression as a negative consequence of FHB infection have been identified, namely lower numbers of kernels in diseased cereal heads and lower weight of infected kernel. This usually results in a lower thousand kernel weight (TKW) and test weight of infected cereals (Mesterházy et al., 2015; Salgado et al., 2015; Martin et al., 2017). The biochemical changes in cereal grain composition as a consequence of FHB could be due to the presence of enzymes produced by the invading fungus or fungi, impaired synthesis of grain components, and incomplete accumulation of kernel constituents due to the mechanical blocking of vascular bundles by fungal mycelium (Kreuzberger et al., 2015).

Please use the following format when citing the article:

Polišenská I., Vaculová K., Jirsa O., Sedláčková I., Frydrych J. 2020. The effect of Fusarium culmorum on yield and grain characteristics of winter wheat cultivars. Zemdirbyste-Agriculture, 107 (2): 113-122. DOI 10.13080/z-a.2020.107.015 
Fusarium spp. can produce enzymes able to modify and decompose stored nutrients in grain, such as proteins and carbohydrates in order to make them more accessible for their utilization (Pekkarinen et al., 2000; Eggert et al., 2011; Schmidt et al., 2016). Changes in wheat crude protein content (Boyacioglu, Hettiarachchy, 1995; Dexter et al., 1996; Häller Gärtner et al., 2008), protein quality (Häller Gärtner et al., 2008; Trümper et al., 2015), falling number (Wang et al., 2008; Papouškova et al., 2011) and rheological properties (Wang et al., 2005; Horvat et al., 2015; Martin et al., 2017) have been observed. The extents of both yield decrease and quality deterioration are related to the extent and severity of infection, but also to cultivar, environmental conditions and also other factors can play a role (Spanic et al., 2017).

The aim of the present study was to compare the response to Fusarium culmorum infection in six winter wheat cultivars differing in baking quality. DON content, grain yield and quality, characterized by test weight, TKW, falling number, crude protein content, sedimentation index, wet gluten content and gluten index, were evaluated in field trials, established within two distinct environments in three successive harvest years. Characteristics of grain harvested from plots artificially infected with $F$. culmorum were compared with those of grain from plots grown under natural infection.

\section{Materials and methods}

Plant material and field trials. Small-plot experiments $\left(10 \mathrm{~m}^{2}\right.$, four replications) were performed in the fields of the Agricultural Research Institute in Kroměříz and OSEVA Development and Research Ltd. in Zubří, the Czech Republic, in the harvest years 2016, 2017 and 2018. Kroměřiž is located within a sugar beet agricultural production area in a warm and moderately wet region, while Zubří is located in a moderately warm climatic region. Characteristics of these locations are presented in Table 1 together with climatic conditions during the growing seasons and data of sowing and harvest.

Table 1. Characteristics of experimental sites and sowing and harvest dates of field trials in the harvest years 2016-2018

\begin{tabular}{|c|c|c|c|c|c|c|}
\hline & \multicolumn{3}{|c|}{ Kroměříž } & \multicolumn{3}{|c|}{ Zubří } \\
\hline Latitude, longitude & \multicolumn{3}{|c|}{$49^{\circ} 17^{\prime} \mathrm{N}, 17^{\circ} 22^{\prime} \mathrm{E}$} & \multicolumn{3}{|c|}{$49^{\circ} 28^{\prime} \mathrm{N}, 18^{\circ} 5^{\prime} \mathrm{E}$} \\
\hline Altitude & \multicolumn{3}{|c|}{$235 \mathrm{~m}$ a.s.l. } & \multicolumn{3}{|c|}{$345 \mathrm{~m}$ a.s.l. } \\
\hline $\begin{array}{l}\text { Average annual } \\
(1971-2010) \text { temperature }\end{array}$ & \multicolumn{3}{|c|}{$9.2^{\circ} \mathrm{C}$} & \multicolumn{3}{|c|}{$7.5^{\circ} \mathrm{C}$} \\
\hline $\begin{array}{l}\text { Average total annual } \\
\text { (1971-2010) precipitation }\end{array}$ & \multicolumn{3}{|c|}{$576 \mathrm{~mm}$} & \multicolumn{3}{|c|}{$865 \mathrm{~mm}$} \\
\hline Soil type & \multirow{2}{*}{\multicolumn{3}{|c|}{$\begin{array}{l}\text { Luvic Chernozem } \\
\text { Silty clay loam }\end{array}$}} & \multirow{2}{*}{\multicolumn{3}{|c|}{$\begin{array}{c}\text { Gleyic Fluvisol } \\
\text { Sandy loam }\end{array}$}} \\
\hline Soil textural class & & & & & & \\
\hline Year & 2015-2016 & 2016-2017 & 2017-2018 & 2015-2016 & 2016-2017 & 2017-2018 \\
\hline Mean temperature ${ }^{1}$ & $9.5^{\circ} \mathrm{C}$ & $8.6^{\circ} \mathrm{C}$ & $9.6^{\circ} \mathrm{C}$ & $8.9^{\circ} \mathrm{C}$ & $7.9^{\circ} \mathrm{C}$ & $8.8^{\circ} \mathrm{C}$ \\
\hline Rainfall $^{1}$ & $474 \mathrm{~mm}$ & $377 \mathrm{~mm}$ & $389 \mathrm{~mm}$ & $713 \mathrm{~mm}$ & $658 \mathrm{~mm}$ & $536 \mathrm{~mm}$ \\
\hline Date of sowing & 26 September & 22 September & 27 September & 13 October & 18 October & 16 October \\
\hline Date of harvest & 20 July & 19 July & 10 July & 27 July & 1 August & 25 July \\
\hline
\end{tabular}

${ }^{1}$ - mean daily temperature and sum of precipitation from 21 September to 31 July

Experiments included six winter wheat (Triticum aestivum L.) cultivars: 'Dagmar', 'Genius', 'Julie', 'Lear', 'Matchball' and 'Tobak' (Table 2). Sowing was done using a seeder Oyord Plotman (Wintersteiger, Austria). The selected cultivars differed in suitability for baking and sensitivity to Fusarium head blight (FHB). As described in the cultivar testing results published by the Czech Central Institute for Supervising and Testing in Agriculture (CISTA) (Horáková, Dvořáčková, 2017) in its List of Recommended Varieties 2017, 'Dagmar' is among the less FHB-susceptible cultivars, 'Genius' and 'Julie' - among the susceptible, and 'Matchball' and 'Tobak' - among the very susceptible cultivars.

In all three years, rapeseed was the preceding crop at Kroměříž, whereas at Zubří it was buckwheat in 2015 and 2016 and white lupine in 2017. Artificial infection with $F$. culmorum was performed by spraying with a water suspension of F. culmorum (isolate KM01) spores at the BBCH 61-64 development stage, when $50 \%$ of the plants were at the onset of flowering; spraying was repeated three days later. The dose of the suspension per plot was $0.02 \mathrm{~L} \mathrm{~m}^{-2}$ and the concentration of the suspension was 500000 conidia $\mathrm{mL}^{-1}$. Description of cultivars and F. culmorum infection dates are presented in Table 2. Meteorological parameters were monitored by meteorological stations located near (approx. $500 \mathrm{~m}$ ) the field experiments at Kroměřiž and Zubří. Treatments with herbicides, insecticides and growth regulators were performed according to the specific situation at the given location while following good plant protection practice. All plots were sprayed with fungicides against leaf diseases at the beginning of stem elongation stage. The total rate of nitrogen in Kroměříž was $120 \mathrm{~kg} \mathrm{ha}^{-1}$, in Zubř́ - $94 \mathrm{~kg} \mathrm{ha}^{-1}$. The plots were harvested with a smallplot harvester Osevan (Oseva Ltd., Czech Republic) at full maturity, each replication individually. Harvested grain was weighed and prepared for analyses.

Grain sample preparation. The harvested grain was cleaned using a Petkus K 541 cleaner/sorter (PETKUS Technologie GmbH, Germany) with a $1 \mathrm{~mm}$ screen, carefully homogenized and divided using a sample divider into subsamples for individual analyses. Part of the grain was set aside for a storage trial (the results are not presented in this paper). Analyses were performed within one month after harvest.

Grain quality analyses. Test weight was determined according to the ISO 7971-3:2009 standard (Cereals - Determination of bulk density, called mass per 
Table 2. Description of winter wheat cultivars and Fusarium culmorum artificial infection dates (first spray, second spray after three days) for field trials at experimental sites Kroměříž (KM) and Zubří (ZB), Czech Republic

\begin{tabular}{|c|c|c|c|c|c|c|c|c|c|}
\hline \multirow{3}{*}{ Cultivar } & \multirow{3}{*}{ QG } & \multirow{3}{*}{ Maintainers } & \multirow{3}{*}{$\begin{array}{l}\text { Year of } \\
\text { registration }\end{array}$} & \multicolumn{6}{|c|}{ F. culmorum infection } \\
\hline & & & & \multicolumn{2}{|c|}{2016} & \multicolumn{2}{|c|}{2017} & \multicolumn{2}{|c|}{2018} \\
\hline & & & & $\mathrm{KM}$ & $\mathrm{ZB}$ & KM & $\mathrm{ZB}$ & $\mathrm{KM}$ & $\mathrm{ZB}$ \\
\hline Dagmar & A & $\begin{array}{l}\text { Limagrain Central Europe } \\
\text { Cereals, s.r.o., CZ }\end{array}$ & 2012 & 30 May & 7 June & 30 May & 8 June & 21 May & 25 May \\
\hline Genius & $\mathrm{E}$ & Nordsaat Saatzucht GmbH, DE & 2010 & 1 June & 7 June & 2 June & 8 June & 23 May & 25 May \\
\hline Julie & $\mathrm{E}$ & Selgen a.s., $\mathrm{CZ}$ & 2014 & 30 May & 7 June & 30 May & 8 June & 21 May & 25 May \\
\hline Lear* & $\mathrm{C}$ & Limagrain $\mathrm{GmbH}, \mathrm{DE}$ & 2010 & 7 June & 10 June & 8 June & 12 June & 27 May & 28 May \\
\hline Matchball & A & RAGT Czech s.r.o., CZ & 2013 & 3 June & 10 June & 6 June & 12 June & 25 May & 28 May \\
\hline Tobak & $\mathrm{B}$ & $\begin{array}{l}\text { W. von Borries-Eckendorf } \\
\text { GmbH \& Co.KG., DE }\end{array}$ & 2011 & 3 June & 10 June & 4 June & 12 June & 25 May & 28 May \\
\hline
\end{tabular}

Note. QG - quality group according to evaluation of Czech Central Institute for Supervising and Testing in Agriculture (Horáková, Dvořáčková, 2017); Czech cultivar quality scheme: E - elite, A - good quality, B - bread, C - non-baking; * - cultivar is registered in another country of the EU and is introduced to the market on the basis of the Common Catalogue of Varieties (https://ec.europa. eu/food/plant/plant_propagation_material/plant_variety_catalogues_databases).

hectolitre) using a quarter-litre measuring container. A thousand kernel weight (TKW) was measured with a seed counter Contador (Pfeuffer GmbH, Germany). Falling number was determined according to ISO 3093:2009 (Determination of the falling number according to Hagberg-Perten) using a Perten LM 3120 mill (Perten, Sweden) and $7 \mathrm{~g}$ of meal on a $15 \%$ moisture basis. Sedimentation index was determined according to ISO 5529:2007 (Wheat - Determination of the sedimentation index - Zeleny test) using a mill Brabender Sedimat (Brabender, Germany). Wet gluten content and gluten index were determined according to the ICC Standard No. 155 (Determination of wet gluten quantity and quality of whole wheat meal and wheat flour). Crude protein content $(\mathrm{N} \times 5.7)$ was determined by the Dumas method according to ICC Standard No. 167 (Determination of crude protein in grain and grain products for food and feed by the Dumas combustion principle) using analysers Leco FP528 and Leco TruMac CNS (LECO Corp., USA).

Deoxynivalenol (DON) analyses. DON was analysed in whole-grain meal flour by ELISA method using R-Biopharm AG kits (Germany), according to the manufacturer's instructions. A combination of RIDASCREEN ${ }^{\circledR}$ DON and RIDACREEN ${ }^{\circledR}$ FAST DON kits was used with the limit of quantification (LOQ) equal to $20 \mu \mathrm{g} \mathrm{kg}^{-1}$. Samples with high contamination were diluted 10 times in distilled water. Whole-grain meal flour was obtained using a sample mill Pulverisette 19 (Fritsch, Germany) with a $1 \mathrm{~mm}$ screen. Samples were stored at $-20^{\circ} \mathrm{C}$ temperature until analyses. The method has been accredited in the laboratory according to standard EN ISO/IEC 17025 (General requirements for the competence of testing and calibration laboratories), and validation was carried out to the extent needed to comply with the standard's requirements.

Statistical analysis. The analytical data are reported here as mean \pm standard deviation from four field replications. For calculations with DON values, the results reported as below LOQ were replaced by half of their respective LOQs (a so-called middle bound estimate). Normality of data was assessed using the Shapiro-Wilk test. The data from three years and two locations were tested by a four-way analysis of variance (ANOVA). Statistical comparison of the means was made using the post-ANOVA Tukey's honestly significant difference test when significant main effects were detected. Log-transformed DON values were used for ANOVA. All calculations were performed using the software Statistica, version 12 (StatSoft Inc., USA). The significance level was set at $p<0.05$.

\section{Results and discussion}

Deoxynivalenol (DON) content in winter wheat cultivars grown under natural Fusarium infection. In plots grown under natural infection, quantifiable amounts of DON (above the LOQ) were found in the cultivars 'Tobak' (Kroměříž: harvests 2016 and 2017, Zubř́: 2018; highest value $289 \mu \mathrm{g} \mathrm{kg}{ }^{-1}$ ), 'Lear' (Kroměříž: 2018, Zubří: 2017 and 2018; highest value $311 \mu \mathrm{g} \mathrm{kg} \mathrm{kg}^{-1}$ ), 'Julie' (Kroměříž: 2016, Zubří: 2018; highest value $84 \mu \mathrm{g} \mathrm{kg}^{-1}$ ) and also in 'Genius' (89 $\left.\mu \mathrm{g} \mathrm{kg}^{-1}\right)$ and 'Matchball' (175 $\left.\mu \mathrm{g} \mathrm{kg}^{-1}\right)$ (Zubří: 2018). In total, DON above LOQ was found in 10 out of 36 $(28 \%)$ non-infected treatments $(6$ cultivars $\times 2$ locations $\times 3$ harvest years) at the highest value of $311 \mu \mathrm{g} \mathrm{kg}^{-1}$. It means that for no harvest year, location or cultivar was the European Union (EU) limit of $1250 \mu \mathrm{g} \mathrm{kg}^{-1}$ for DON content in bread wheat exceeded. According to the EFSA (2013) report, which was based on the data collected by 21 EU countries, DON was found in $45 \%$ of unprocessed grain samples, but only $0.8 \%$ of samples exceeded the legal limit.

Results of our experiment confirmed, that DON can be found quite commonly in wheat grain but that it is not very common to exceed the legal limits. To the low DON content in plots grown under natural infection could contribute the fact, that in our trials neither maize nor cereals were chosen as preceding crop and, therefore, the primary infection from crop debris was mostly avoided. The content of DON in plots grown under natural infection was significantly influenced mainly by the cultivar ( $25 \%$ contribution to variability), but also harvest year (Y) $(11 \%)$ and location (L) $(5 \%)$, with the interaction $\mathrm{Y} \times \mathrm{L}$ being the most important $(39 \%$ contribution to variability) among all factors and their interactions (Table 3). Compared to all other cultivars tested in the trial, 'Tobak' proved to be significantly more DON susceptible cultivar $(p<0.001)$. 
Table 3. Analysis of variance of deoxynivalenol (DON) content in six winter wheat cultivars $(\mathrm{C})$ grown at two different locations (L) in three harvest years (Y) under natural Fusarium infection

\begin{tabular}{cccc}
\hline & DF & Sum of squares & $p$ \\
\hline Year (Y) & 2 & 24.1 & 0.0000 \\
Location (L) & 1 & 10.9 & 0.0000 \\
Cultivar (C) & 5 & 53.9 & 0.0000 \\
$\mathrm{Y} \times \mathrm{L}$ & 2 & 84.2 & 0.0000 \\
$\mathrm{Y} \times \mathrm{C}$ & 10 & 9.6 & 0.0164 \\
$\mathrm{~L} \times \mathrm{C}$ & 5 & 7.6 & 0.0041 \\
$\mathrm{Y} \times \mathrm{L} \times \mathrm{C}$ & 10 & 14.3 & 0.0011 \\
\hline Error & 36 & 13.1 & \\
Total & 71 & 217.7 & \\
\hline
\end{tabular}

Note. DF - degree of freedom; for DON values, logarithmic transformation was performed.
The results confirm the multi-factorial nature of FHB disease and also put emphasize on the fact, that although there is no fully resistant wheat cultivar available, there are substantial differences among the currently grown ones.

Impact of Fusarium culmorum infection. Considering the entire data set from the whole trial, artificial infection systematically impacted all the considered variables with the exception of wet gluten content (ANOVA) (Table 4). There were significant interactions of $F$. culmorum infection with other factors in most cases.

DON content in winter wheat cultivars infected by the F. culmorum was strongly influenced by the infection. It explained $63 \%$ of the DON content variability in harvested wheat grain (Table 4). Although $F$. graminearum prevailed over $F$. culmorum on wheat nowadays in Europe (Bilska et al., 2018), F. culmorum is still used for $F$. culmorum infection in similar

Table 4. Analysis of variance (ANOVA) of deoxynivalenol (DON) content and quality parameters in six winter wheat cultivars (C), grown at two different locations (L) in three harvest years (Y), with or without (I) artificial Fusarium culmorum infection

\begin{tabular}{cccccccccc}
\hline & DON & Yield & TKW & TW & FN & SEDI & WGC & GI & CPC \\
\hline Y & 0.0000 & 0.0000 & 0.0000 & 0.0000 & 0.0000 & 0.0000 & 0.0000 & 0.0000 & 0.0000 \\
L & 0.0000 & 0.0000 & 0.0000 & 0.0000 & 0.0000 & 0.0000 & 0.0000 & 0.0000 & 0.0000 \\
C & 0.0000 & 0.0000 & 0.0000 & 0.0000 & 0.0000 & 0.0000 & 0.0000 & 0.0000 & 0.0000 \\
I & 0.0000 & 0.0000 & 0.0000 & 0.0000 & 0.0000 & 0.0000 & 0.5399 & 0.0000 & 0.0000 \\
$\mathrm{Y} \times \mathrm{L}$ & 0.0000 & 0.0000 & 0.0000 & 0.0000 & 0.0000 & 0.0000 & 0.0000 & 0.0000 & 0.0000 \\
$\mathrm{Y} \times \mathrm{C}$ & 0.0003 & 0.0000 & 0.0000 & 0.0000 & 0.0000 & 0.0000 & 0.0000 & 0.0002 & 0.0000 \\
$\mathrm{~L} \times \mathrm{C}$ & 0.0000 & 0.0000 & 0.0005 & 0.0000 & 0.0000 & 0.0000 & 0.0000 & 0.0000 & 0.0000 \\
$\mathrm{Y} \times \mathrm{I}$ & 0.0000 & 0.0000 & 0.0000 & 0.0000 & 0.0000 & 0.0000 & 0.0009 & 0.0000 & 0.0000 \\
$\mathrm{~L} \times \mathrm{I}$ & 0.0000 & 0.0000 & 0.0000 & 0.0000 & 0.1479 & 0.0000 & 0.0000 & 0.0000 & 0.0000 \\
$\mathrm{C} \times \mathrm{I}$ & 0.0001 & 0.0000 & 0.5406 & 0.0000 & 0.0001 & 0.0000 & 0.0002 & 0.0001 & 0.0000 \\
$\mathrm{Y} \times \mathrm{L} \times \mathrm{C}$ & 0.0011 & 0.0000 & 0.0000 & 0.0000 & 0.0000 & 0.0000 & 0.0000 & 0.0000 & 0.0000 \\
$\mathrm{Y} \times \mathrm{L} \times \mathrm{I}$ & 0.0000 & 0.0000 & 0.0000 & 0.0000 & 0.0038 & 0.0000 & 0.0000 & 0.0000 & 0.0000 \\
$\mathrm{Y} \times \mathrm{C} \times \mathrm{I}$ & 0.0001 & 0.0067 & 0.0017 & 0.0000 & 0.0014 & 0.0000 & 0.0000 & 0.0005 & 0.0000 \\
$\mathrm{~L} \times \mathrm{C} \times \mathrm{I}$ & 0.0008 & 0.0000 & 0.6131 & 0.0000 & 0.0054 & 0.0000 & 0.0005 & 0.0023 & 0.0000 \\
$\mathrm{Y} \times \mathrm{L} \times \mathrm{C} \times \mathrm{I}$ & 0.0000 & 0.0002 & 0.0008 & 0.0000 & 0.0919 & 0.0000 & 0.0000 & 0.0004 & 0.0000 \\
\hline
\end{tabular}

Note. TKW - thousand kernel weight, TW - test weight, FN - falling number, SEDI - sedimentation index, WGC - wet gluten content, GI - gluten index, CPC - crude protein content; results are shown as $p$ values; for DON values, logarithmic transformation was performed.

model studies (e.g., Schmidt et al., 2016). According to Mesterházy et al. (2005), the resistance of wheat genotypes to $F$. graminearum is similar to that for other Fusarium spp., including $F$. culmorum. Apart from $F$. culmorum infection, DON was significantly influenced by all tested factors and their mutual interactions, mainly by cultivar, harvest year and location. The level of DON content in three harvest years was significantly higher $(p<0.001)$ at Kroměříž than at Zubří (Fig. 2A, B and C).

At Kroměříž, the DON means over all cultivars were $10355 \pm 6085 \mu \mathrm{g} \mathrm{kg}^{-1}$ in $2016,859 \pm 855 \mu \mathrm{g} \mathrm{kg}^{-1}$ in 2017 and $17508 \pm 11160 \mu \mathrm{g} \mathrm{kg}^{-1}$ in 2018 , whereas at Zubř́ these were $911 \pm 805 \mu \mathrm{g} \mathrm{kg}^{-1}, 174 \pm 128 \mu \mathrm{g} \mathrm{kg}^{-1}$ and $327 \pm 225 \mu \mathrm{g} \mathrm{kg}^{-1}$, respectively.

Differences between harvest years were significant $(p<0.001)$ as well as differences between cultivars. Ranking of cultivars based on DON content was in descending order as follows: 'Tobak' > 'Lear' > 'Genius'> 'Julie'> 'Matchball'> 'Dagmar'. In accordance with the tests of the CISTA (Horáková, Dvořáčková, 2017), the lower susceptibility of 'Dagmar' and the considerable susceptibility of 'Tobak' was confirmed. Cultivar 'Matchball', which the CISTA ranking places in the same susceptibility group as 'Tobak', was in our experiments ranked between 'Julie' (susceptible) and 'Dagmar' (less susceptible), whereas 'Lear' between 'Tobak' (highly susceptible) and 'Genius' (susceptible).

The data of our experiment revealed the number of interactions that significantly influenced DON content. The complex nature of the host, pathogen and environment interactions is the main reason, why FHB is so difficult to control (Spanic et al., 2017). The cultivation of resistant cultivars is the most sustainable and cost-effective way to control yield losses and mycotoxin contamination (McMullen et al., 2012) and could be an intrinsic part of crop protection strategy. The main challenge in cereal protection against FHB is to 
Table 5. Qualitative parameters of six winter wheat cultivars grown at two locations (Kroměříž and Zubří) and the change after Fusarium culmorum infection

\begin{tabular}{|c|c|c|c|c|c|c|c|c|}
\hline $\begin{array}{l}\text { Location / } \\
\text { cultivar }\end{array}$ & $\begin{array}{l}\text { Yield } \\
\mathrm{t} \mathrm{ha}^{-1}\end{array}$ & $\begin{array}{c}\mathrm{TW} \\
\mathrm{kg} \mathrm{hl}^{-1}\end{array}$ & $\begin{array}{c}\text { TKW } \\
\mathrm{g}\end{array}$ & $\begin{array}{c}\mathrm{FN} \\
\mathrm{s}\end{array}$ & $\begin{array}{c}\text { SEDI } \\
\mathrm{ml}\end{array}$ & $\underset{\%}{\mathrm{CPC}}$ & $\begin{array}{c}\text { WGC } \\
\%\end{array}$ & GI \\
\hline \multicolumn{9}{|c|}{ Kroměříž } \\
\hline Dagmar & $\begin{array}{c}10.4 \pm 2.0 \\
(-10.5 \%)^{* * *}\end{array}$ & $\begin{array}{l}81.5 \pm 1.4 \\
(-3.5 \%)^{* * *}\end{array}$ & $\begin{array}{c}43.0 \pm 3.1 \\
(-7 \%)^{* *}\end{array}$ & $\begin{array}{c}364 \pm 16 \\
(-1 \%)\end{array}$ & $\begin{array}{c}42 \pm 5 \\
(-13 \%)^{* * *}\end{array}$ & $\begin{array}{l}12.2 \pm 1.0 \\
(+4 \%)^{* * * *}\end{array}$ & $\begin{array}{c}31.2 \pm 3.7 \\
\quad(+4 \%)\end{array}$ & $\begin{array}{c}87 \pm 12 \\
(-30 \%)^{* * *}\end{array}$ \\
\hline Genius & $\begin{array}{c}10.2 \pm 2.1 \\
(-13.3 \%)^{* * *}\end{array}$ & $\begin{array}{l}80.2 \pm 2.3 \\
(-6.1 \%)^{* * *}\end{array}$ & $\begin{array}{l}36.7 \pm 3.3 \\
(-9 \%)^{* * *}\end{array}$ & $\begin{array}{l}412 \pm 12 \\
(-7 \%)^{* *}\end{array}$ & $\begin{array}{c}49 \pm 9 \\
(-20 \%)^{* * *}\end{array}$ & $\begin{array}{c}13.5 \pm 0.8 \\
(+3 \%)^{* *}\end{array}$ & $\begin{array}{c}35.0 \pm 3.2 \\
\quad(+4 \%)\end{array}$ & $\begin{array}{c}87 \pm 5 \\
(-34 \%)^{* * *}\end{array}$ \\
\hline Julie & $\begin{array}{c}11.1 \pm 2.1 \\
(-19.0 \%)^{* * *}\end{array}$ & $\begin{array}{l}80.5 \pm 1.4 \\
(-7.1 \%)^{* * *}\end{array}$ & $\begin{array}{l}43.0 \pm 4.1 \\
(-10 \%)^{* * *}\end{array}$ & $\begin{array}{c}372 \pm 26 \\
(-1 \%)\end{array}$ & $\begin{array}{c}49 \pm 5 \\
(-25 \%)^{* * *}\end{array}$ & $\begin{array}{c}13.0 \pm 0.5 \\
(-0 \%)\end{array}$ & $\begin{array}{c}32.5 \pm 2.8 \\
(-0 \%)\end{array}$ & $\begin{array}{c}94 \pm 2 \\
(-39 \%)^{* * *}\end{array}$ \\
\hline Lear & $\begin{array}{c}11.1 \pm 1.7 \\
(-23.7 \%)^{* * *}\end{array}$ & $\begin{array}{c}75.5 \pm 3.2 \\
(-8.4 \%)^{* * *}\end{array}$ & $\begin{array}{c}34.9 \pm 2.4 \\
(-11 \%)^{* * *}\end{array}$ & $\begin{array}{c}225 \pm 14 \\
(+6 \%)\end{array}$ & $\begin{array}{l}20 \pm 2 \\
(-8 \%)^{*}\end{array}$ & $\begin{array}{l}11.9 \pm 0.7 \\
(+8 \%)^{* * * *}\end{array}$ & $\begin{array}{c}31.2 \pm 2.9 \\
(+3 \%)\end{array}$ & $\begin{array}{c}56 \pm 9 \\
(-20 \%)^{*}\end{array}$ \\
\hline Matchball & $\begin{array}{c}11.3 \pm 2.2 \\
(-14.0 \%)^{* * *}\end{array}$ & $\begin{array}{c}77.2 \pm 3.0 \\
(-4.1 \%)^{* * *}\end{array}$ & $\begin{array}{c}34.4 \pm 3.9 \\
(-9 \%)^{* *}\end{array}$ & $\begin{array}{c}376 \pm 14 \\
(-4 \%)\end{array}$ & $\begin{array}{l}30 \pm 4 \\
(-3 \%)\end{array}$ & $\begin{array}{l}12.2 \pm 1.2 \\
(+7 \%)^{* * *}\end{array}$ & $\begin{array}{c}30.1 \pm 3.6 \\
\quad(+4 \%)\end{array}$ & $\begin{array}{c}74 \pm 10 \\
(-37 \%)^{* * *}\end{array}$ \\
\hline Tobak & $\begin{array}{c}10.5 \pm 2.0 \\
(-24.1 \%)^{* * *} \\
\end{array}$ & $\begin{array}{c}75.7 \pm 2.4 \\
(-9.0 \%)^{* * *}\end{array}$ & $\begin{array}{c}35.7 \pm 2.2 \\
(-12 \%)^{* * *}\end{array}$ & $\begin{array}{c}358 \pm 18 \\
(-4 \%)\end{array}$ & $\begin{array}{c}35 \pm 5 \\
(-20 \%)^{* * *} \\
\end{array}$ & $\begin{array}{l}12.4 \pm 1.3 \\
(+6 \%)^{* * *}\end{array}$ & $\begin{array}{c}33.4 \pm 5.6 \\
(+3 \%)\end{array}$ & $\begin{array}{c}69 \pm 14 \\
(-46 \%)^{* * *} \\
\end{array}$ \\
\hline Mean & $10.8 \pm 2.0 \mathrm{~A}$ & $78.4 \pm 3.3 \mathrm{~A}$ & $37.9 \pm 4.8 \mathrm{~B}$ & $351 \pm 62 \mathrm{~A}$ & $37 \pm 12 \mathrm{~A}$ & $12.5 \pm 1.0 \mathrm{~A}$ & $32.2 \pm 3.8 \mathrm{~A}$ & $78 \pm 16 \mathrm{~B}$ \\
\hline \multicolumn{9}{|c|}{ Zubří } \\
\hline Dagmar & $\begin{array}{l}7.7 \pm 2.1 \\
(+2.4 \%)\end{array}$ & $\begin{array}{c}78.5 \pm 0.8 \\
(-0.1 \%)\end{array}$ & $\begin{array}{c}46.3 \pm 1.8 \\
(-0 \%)\end{array}$ & $\begin{array}{c}285 \pm 69 \\
(-4 \%)\end{array}$ & $\begin{array}{c}30 \pm 11 \\
(-4 \%)\end{array}$ & $\begin{array}{l}10.2 \pm 1.3 \\
(+5 \%)^{* * *}\end{array}$ & $\begin{array}{c}24.0 \pm 8.1 \\
(-2 \%)\end{array}$ & $\begin{array}{l}93 \pm 6 \\
(-5 \%)\end{array}$ \\
\hline Genius & $\begin{array}{l}8.1 \pm 2.0 \\
(-2.8 \%)\end{array}$ & $\begin{array}{c}78.4 \pm 0.3 \\
(-0.5 \%)\end{array}$ & $\begin{array}{l}41.8 \pm 1.0 \\
(+1 \%)\end{array}$ & $\begin{array}{c}363 \pm 20 \\
(-2 \%)\end{array}$ & $\begin{array}{c}37 \pm 6 \\
(-7 \%)^{* * *}\end{array}$ & $\begin{array}{c}11.1 \pm 0.7 \\
(+2 \%)\end{array}$ & $\begin{array}{l}27.9 \pm 7.2 \\
(-9 \%)^{* * *}\end{array}$ & $\begin{array}{l}92 \pm 7 \\
(-5 \%)\end{array}$ \\
\hline Julie & $\begin{array}{l}7.7 \pm 2.5 \\
(-0.7 \%)\end{array}$ & $\begin{array}{c}78.6 \pm 0.8 \\
(-0.7 \%)\end{array}$ & $\begin{array}{l}48.1 \pm 1.9 \\
\quad(+1 \%)\end{array}$ & $\begin{array}{c}303 \pm 38 \\
(-4 \%)\end{array}$ & $\begin{array}{c}38 \pm 11 \\
(-7 \%)^{* * *}\end{array}$ & $\begin{array}{c}11.2 \pm 1.2 \\
(+2 \%)\end{array}$ & $\begin{array}{c}28.3 \pm 7.8 \\
(-7 \%)^{*}\end{array}$ & $\begin{array}{l}90 \pm 8 \\
(+0 \%)\end{array}$ \\
\hline Lear & $\begin{array}{l}8.3 \pm 2.0 \\
(+1.5 \%)\end{array}$ & $\begin{array}{c}74.2 \pm 1.5 \\
(-0.9 \%)\end{array}$ & $\begin{array}{c}39.4 \pm 0.7 \\
\quad(+1 \%)\end{array}$ & $\begin{array}{c}187 \pm 15 \\
(-1 \%)\end{array}$ & $\begin{array}{c}14 \pm 1 \\
(+19 \%)^{* * *}\end{array}$ & $\begin{array}{c}9.7 \pm 0.2 \\
(+4 \%)^{*}\end{array}$ & $\begin{array}{c}23.9 \pm 2.3 \\
(+4 \%)\end{array}$ & $\begin{array}{c}81 \pm 13 \\
(+2 \%)\end{array}$ \\
\hline Matchball & $\begin{array}{l}8.9 \pm 1.5 \\
(-7.1 \%)\end{array}$ & $\begin{array}{c}75.4 \pm 2.2 \\
(+1.0 \%)\end{array}$ & $\begin{array}{c}38.9 \pm 1.2 \\
(-0 \%)\end{array}$ & $\begin{array}{c}339 \pm 20 \\
(-4 \%)\end{array}$ & $\begin{array}{l}22 \pm 5 \\
(-6 \%)\end{array}$ & $\begin{array}{c}10.0 \pm 0.8 \\
(+0 \%)\end{array}$ & $\begin{array}{c}23.2 \pm 6.1 \\
(-7 \%)\end{array}$ & $\begin{array}{c}82 \pm 17 \\
(+3 \%)\end{array}$ \\
\hline Tobak & $\begin{array}{l}8.6 \pm 1.3 \\
(-5.6 \%) \\
\end{array}$ & $\begin{array}{c}73.4 \pm 2.0 \\
(+0.2 \%) \\
\end{array}$ & $\begin{array}{c}39.9 \pm 3.0 \\
(-1 \%)\end{array}$ & $\begin{array}{c}310 \pm 25 \\
(-12 \%)^{* * *} \\
\end{array}$ & $\begin{array}{l}25 \pm 7 \\
(-5 \%) \\
\end{array}$ & $\begin{array}{c}9.6 \pm 1.3 \\
(+9 \%)^{* * *}\end{array}$ & $\begin{array}{c}23.3 \pm 7.7 \\
(+4 \%)\end{array}$ & $\begin{array}{c}86 \pm 12 \\
(-1 \%) \\
\end{array}$ \\
\hline Mean & $8.2 \pm 1.9 \mathrm{~B}$ & $76.4 \pm 2.6 \mathrm{~B}$ & $42.4 \pm 4.0 \mathrm{~A}$ & $298 \pm 66 \mathrm{~B}$ & $28 \pm 11 \mathrm{~B}$ & $10.3 \pm 1.1 \mathrm{~B}$ & $25.1 \pm 6.7 \mathrm{~B}$ & $87 \pm 11 \mathrm{~A}$ \\
\hline
\end{tabular}

Note. TW - test weight, TKW - thousand kernel weight, FN - falling number, SEDI - sedimentation index, CPC - crude protein content, WGC - wet gluten content, GI - gluten index, ${ }^{* *}$ - significant at $p<0.05, * * *$ - significant at $p<0.001$; different letters indicate significant differences between means at $p<0.05$; results shown are mean year values \pm confidence interval, percentage change after infection is in brackets.

combine the most effective measures in an integrative approach (Miedaner et al., 2017).

Yield, thousand kernel weight (TKW) and test weight. Grain yield was significantly reduced by the F. culmorum infection over the whole data set (ANOVA) (Table 4). Significant impact was observed at Kroměř́̌ž, and that in 2016 for all cultivars (in the mean by $24 \%$, ranging from $16 \%$ to $32 \%$ ) and in 2018 for all cultivars, except for 'Dagmar' (in the mean by $22 \%$, ranging from $18 \%$ to $36 \%$ ). The yield of 'Dagmar' was lower by $8 \%$, but the change was not significant. The most influencing factor of yield was harvest year (explaining 60\% of variability), location (15\%) and infection (6\%), with all of mutual interactions also being significant. At Kroměříž, yield was higher $\left(10.8 \pm 2.0 \mathrm{t} \mathrm{ha}^{-1}\right)$ than at Zubří $(8.2$ $\left.\pm 1.9 \mathrm{t} \mathrm{ha}^{-1}\right)$. Similarly to yield, a significant reduction in TKW and test weight due to infection occurred at Kroměříž only and was observed there for all cultivars (Table 5). The largest reduction in TKW and test weight occurred in the 'Tobak' (TKW by $12 \%$ and test weight by $9 \%$ ) and the smallest reduction in 'Dagmar' (TKW by $7 \%$ and test weight by $3.5 \%$ ). Test weight was the second most influenced parameter (after gluten index) by the infection, which explained $9.4 \%$ of the total test weight variability. Reduction in yield, test weight and TKW is a known consequence of wheat infection with FHB (Papouškova et al., 2011; Mesterházy et al., 2015; Spanic et al., 2017), and models have been developed describing the FHB $\times$ yield and FHB $\times$ test weight relationships (Blandino et al., 2012; Salgado et al., 2015). The ability to maintain grain volume, measured as reduction of TKW and test weight is, besides the accumulation of DON, an important characteristic of wheat resistance to FHB (Martin et al., 2017). In our experiment, DON content in wheat grain below $1000 \mu \mathrm{g} \mathrm{kg}^{-1}$ was related neither to decrease of yield nor TKW and test weight, as was shown at Zubří in all experimental (2016-2018) years and at Kroměříž in 2017.

Falling number. Although falling number was influenced by the F. culmorum infection significantly, it was the least influenced parameter and infection accounted for only less than $1 \%$ of falling number total variance. The most important factor for falling number was cultivar (explaining $65 \%$ of variability), followed by location (18\%) and harvest year (2\%), with many mutual interactions. However, there was no interaction between F. culmorum infection and location (ANOVA) (Table 4). Significant reduction in falling number was measured for 'Tobak' grown at Zubří (reduction by 12\%) and 'Genius' grown at Kroměříž (reduction by 7\%) (Table 5). 
Fungal infection of ears increases degradation of starch due to the presence of enzymes, such as $\alpha$-amylase, the activity of which is measured using falling number (Wang et al., 2008). A reduction of falling number after infection with Fusarium fungi could, therefore, be expected and has been confirmed, e.g., by Dexter et al. (1996) in heavily infected kernels and by Siuda et al. (2010) in general.

Falling number in wheat grain depends mainly on climatic conditions during ripening stage and harvest. The weather conditions in all experimental years of our study were favourable for achieving good falling number. In average of all cultivars and harvest years, falling number at Kroměříž was $351 \pm 62 \mathrm{~s}$, at Zubří $-298 \pm 66$ s. A cultivar-specific reaction to FHB was observed by Häller Gärtner et al. (2008), whereby falling number remained unchanged by the infection in resistant cultivars. In our experiment, reduced falling number was observed in 'Tobak', the most FHB-susceptible cultivar in the trial and in susceptible 'Genius'. In 'Lear', the second most susceptible cultivar after 'Tobak', the decrease of falling number was not observed as a consequence of $F$. culmorum infection. Under natural infection, of all cultivars 'Lear' had the lowest falling number (at Kroměříž $225 \pm 14$ s, at Zubří $187 \pm 15$ s), and its reaction to infection was non-significant and hardly any (at Kroměříž $-1 \%$, at Zubří $+6 \%$ ) in spite of a high DON content (at least at Kroměříž $10230 \pm$ $9730 \mu \mathrm{g} \mathrm{kg}^{-1}$, at Zubř́i $\left.805 \pm 698 \mu \mathrm{g} \mathrm{kg} \mathrm{kg}^{-1}\right)$. As stated by Wang et al. (2008), the relationship between FHB infection and falling number may not be simple and straightforward. They found a statistically significant positive relationship between FHB infection level and fungal $\alpha$-amylase and suggested, that the method used for falling number analysis is not adequate enough for the true determination of the $\alpha$-amylase activity of fungusinfected wheat flour.

Crude protein content. Significant increase in crude protein content as a consequence of $F$. culmorum infection was proved at both locations (Table 5). At Kroměříž, it was measured in 5 cultivars out of the total 6 ('Julie' being the exception), with the crude protein content increase by 3-8\%. At Zubří, an increase occurred in three cultivars ('Dagmar', 'Lear' and 'Tobak') with similar range of the increase (by 4-9\%). Among the three cultivars, in which crude protein content remained unchanged after infection, there were two E-quality cultivars ('Julie', in which crude protein content was unchanged at either location, and 'Genius' at Zubří) and one A-quality cultivar ('Matchball' at Zubří). Information from the literature concerning the influence of FHB infection on crude protein content in wheat grain is not consistent. Whereas some studies have observed a light reduction in crude protein content after Fusarium infection (Häller Gärtner et al., 2008), others have reported an increase (Boyacioglu, Hettiarachchy, 1995), and still others have seen no change (Wang et al., 2005; Eggert et al., 2010; Kreuzberger et al., 2015). Dexter et al. (1996) found cultivar-dependent response but generally not closely related to the damage caused by Fusarium. Siuda et al. (2010) observed the change in crude protein content to depend upon the degree of infestation with crude protein content showing higher values for moderately infested kernels than for kernels either lightly or heavily infested. Martin et al. (2017) reported only negligible impact of the Fusarium infection on the total grain protein content and demonstrated the significant interactions between genotype, environment and infection. This was confirmed also by our experimental results. Even though the influence of infection was significant, it explained only $2 \%$ of the total variability and was subjected to interactions with environment and cultivar. The strongest factor influencing crude protein content was location (explaining $50 \%$ of variability) with significantly higher crude protein content at Kroměříž than at Zubří, followed by harvest year (18\%) and cultivar (9\%).

Sedimentation index, wet gluten content and gluten index. F. culmorum infection explained $2.5 \%$ of sedimentation index variability. It was the parameter the most subjected to interaction between cultivar and infection, which indicates that it was not affected to the same extent in all the genotypes. Significant decrease was measured at Kroměříž in 5 cultivars out of 6 (the exception being 'Matchball'), for individual cultivars - by $8-25 \%$. At Zubř́, decrease of sedimentation index was observed only in 'Julie' and 'Genius' (both by 7\%). In contrast, there occurred a significant increase in sedimentation index in the 'Lear' $(+19 \%)$ at Zubří (Table 5). This may be connected with a very low sedimentation index value in 'Lear' grown at Zubří under natural infection (14 \pm 1 $\mathrm{mL}$ ). 'Lear' is a cultivar characterized by a low protein quality. According to Horáková and Dvořáčková (2017), it is rated as C-quality, e.g., non-baking cultivar. This was enhanced by low crude protein content level at Zubří in general. A decrease in protein quality, expressed by sedimentation index, selectively only in some cultivars has been observed also by Häller Gärtner et al. (2008), whereas Papouškova et al. (2011) reported a reduction after infection with FHB generally. Wang et al. (2005) found significantly lower sedimentation value in heavily infected samples compared with samples with a low infection level. On the other hand, Kreuzberger et al. (2015) did not observe a change in sedimentation index in flours with higher DON content. In our trial a significant decrease of sedimentation index was observed for two treatments with DON content $<500 \mu \mathrm{g} \mathrm{kg}$, namely cultivars 'Julie' and 'Genius' grown at Zubří. For these two treatments also significant decrease of wet gluten content was observed, as for the only two cases in the whole trial. Apart from F. culmorum infection, sedimentation index was influenced the most by cultivar $(52 \%$ contribution to variability), followed by harvest year (11\%) and location $(10 \%)$. All interactions of the evaluated factors were also significant. Wet gluten content was the only qualitative parameter analysed, which was not directly influenced by the infection itself considering the entire data set from the whole trial (ANOVA) (Table 4), but there were significant interactions of infection with location and cultivar. For individual locations, a significant increase in wet gluten content by $3 \%$ was measured at Kroměříž but significant decrease at Zubří, also by 3\%. The most important factor influencing wet gluten content was the environment: harvest year by $38 \%$, location by $33 \%$. Siuda et al. (2010) observed higher both wet gluten and crude protein 
content values for moderately infested kernels than for kernels either lightly or heavily infested. Kreuzberger et al. (2015) observed no change in wet gluten content after FHB infection, but they did find changes in gluten composition, namely in the gliadin to glutenin ratio, which is in agreement also with Wang et al. (2005) and Eggert et al. (2010).

In our study, gluten quality, as expressed by gluten index, was substantially reduced after F. culmorum infection in all cultivars at Kroměřiž (by 20-46\%). This decrease was the most pronounced in the 'Tobak' and the least in 'Lear'. However, the latter had very low gluten index under natural infection $(56 \pm 9 \mathrm{ml})$. At Zubř́, no significant change in gluten index due to infection was observed. Gluten index was the parameter the most influenced by the infection, which explained $10.5 \%$ of the total gluten index variability.

Results at individual experimental sites. Zubří is location generally less suitable for growing bread wheat because of poorer soil conditions and harsher weather conditions. Under natural Fusarium infection, a lower yield, test weight, falling number, crude protein content, sedimentation index and wet gluten content were achieved at Zubří in comparison with Kroměříž. On the other hand, TKW and gluten index were higher at Zubří (Table 5). Precipitation was more abundant at Zubř́i in all years of the experiment, both in the vegetation season as a whole (Table 1) and during anthesis and the beginning of grain filling (Fig. 1A and B).
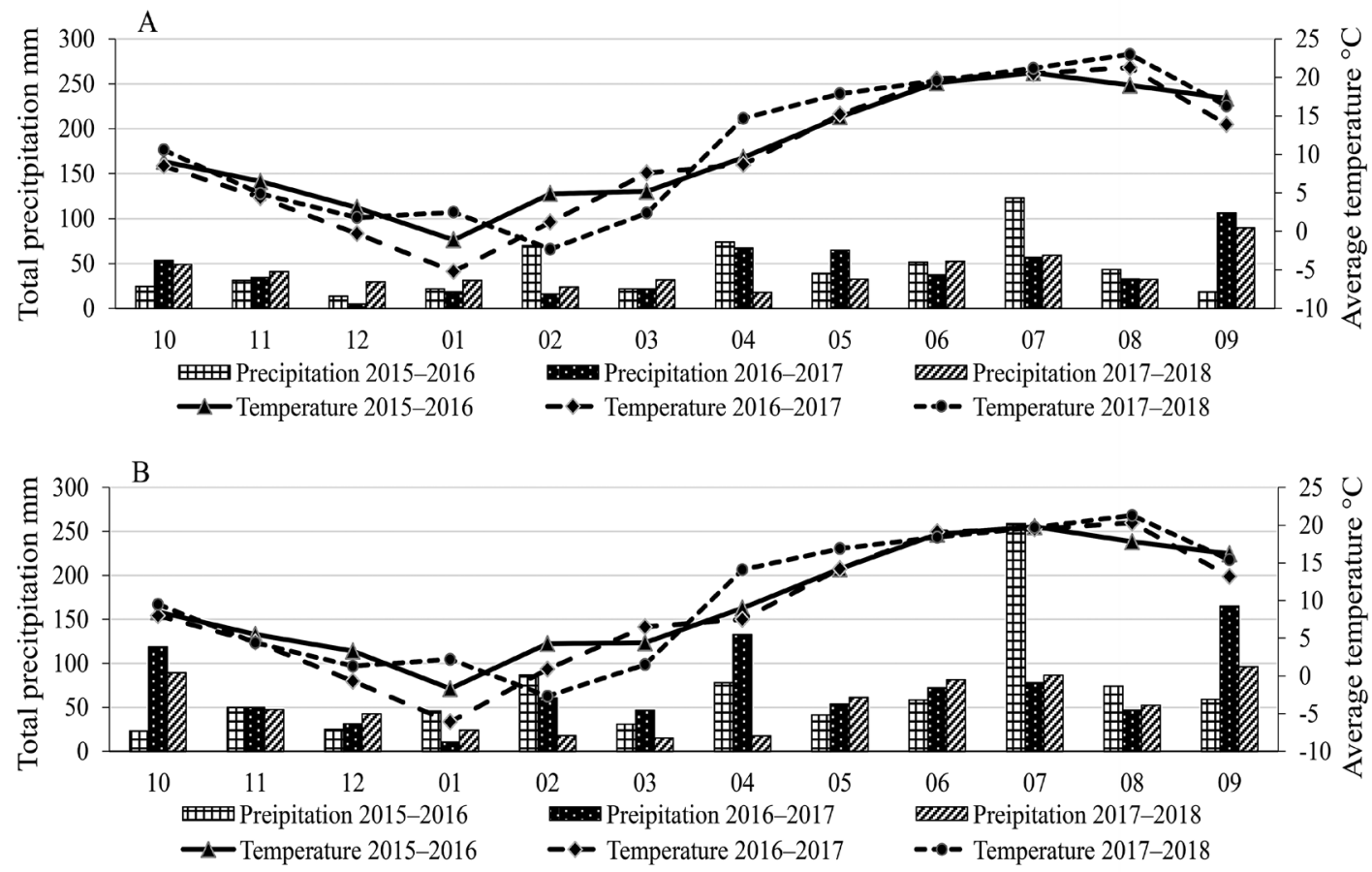

Figure 1. Monthly mean temperature and sum of precipitation for experimental sites (A - Kroměříž, B - Zubří) in the harvest years 2016-2018

Under conditions of natural Fusarium infection, the DON level was significantly higher at Zubř́ in 2018, in comparison with all other environments (both locations in 2016 and 2017, Kroměříž in 2018). Nevertheless, F. culmorum artificial infection, as measured by DON content, had much stronger impact at Kroměříz than at Zubří (Fig. 2A, B and C).

As a result of $F$. culmorum infection, significant reduction of yield, test weight, TKW and gluten index was observed at Kroměříž but not at Zubř́ (Table 5). Gluten index and test weight were the parameters the most influenced by the infection in the frame of the whole data set, as the infection explained $10.5 \%$ and $9.4 \%$ of their total variability, respectively. Yield with $6 \%$ and TKW with $2.6 \%$ of attributed variability as a consequence of infection followed them in importance.

Changes in falling number, sedimentation index and crude protein content were observed at both locations. Although significant reduction in sedimentation index was observed at both locations, at Zubř́i it reached much lesser extent: in the mean at Kroměříž by $16 \%$, at Zubř́i by $4 \%$. For crude protein content and falling number, no or only negligible interaction of $F$. culmorum infection with location was observed. An increase in crude protein content after infection, was observed at Kroměříž in 5 cultivars (in the mean by $5 \%$ ) and at Zubří in 3 cultivars (in the mean by $4 \%$ ).

Reaction of falling number was rather weak and manifested itself by reduction in one cultivar at Kroměříž ('Genius') and one cultivar at Zubří ('Tobak'). After F.culmorum infection, wet gluten content was slightly, but significantly higher at Kroměříž but lower at Zubří, and it was the only parameter, which was not significantly influenced by the infection considering the whole data set (Table 4). At Kroměř́ž, change in wet gluten content was not proved for any specific cultivar but only in the frame of the entire location, in contrast to Zubří, when wet gluten content was significantly lower after infection for 'Genius' and 'Julie'. This contradictory reaction may be connected with very low wet gluten content in general at Zubří $(25.1 \pm 6.7 \%)$ in comparison with Kroměřiž $(32.2 \pm 3.8 \%)$. 'Genius' and 'Julie' were the only cultivars, for which decrease in gluten quality as measured by sedimentation index was observed 

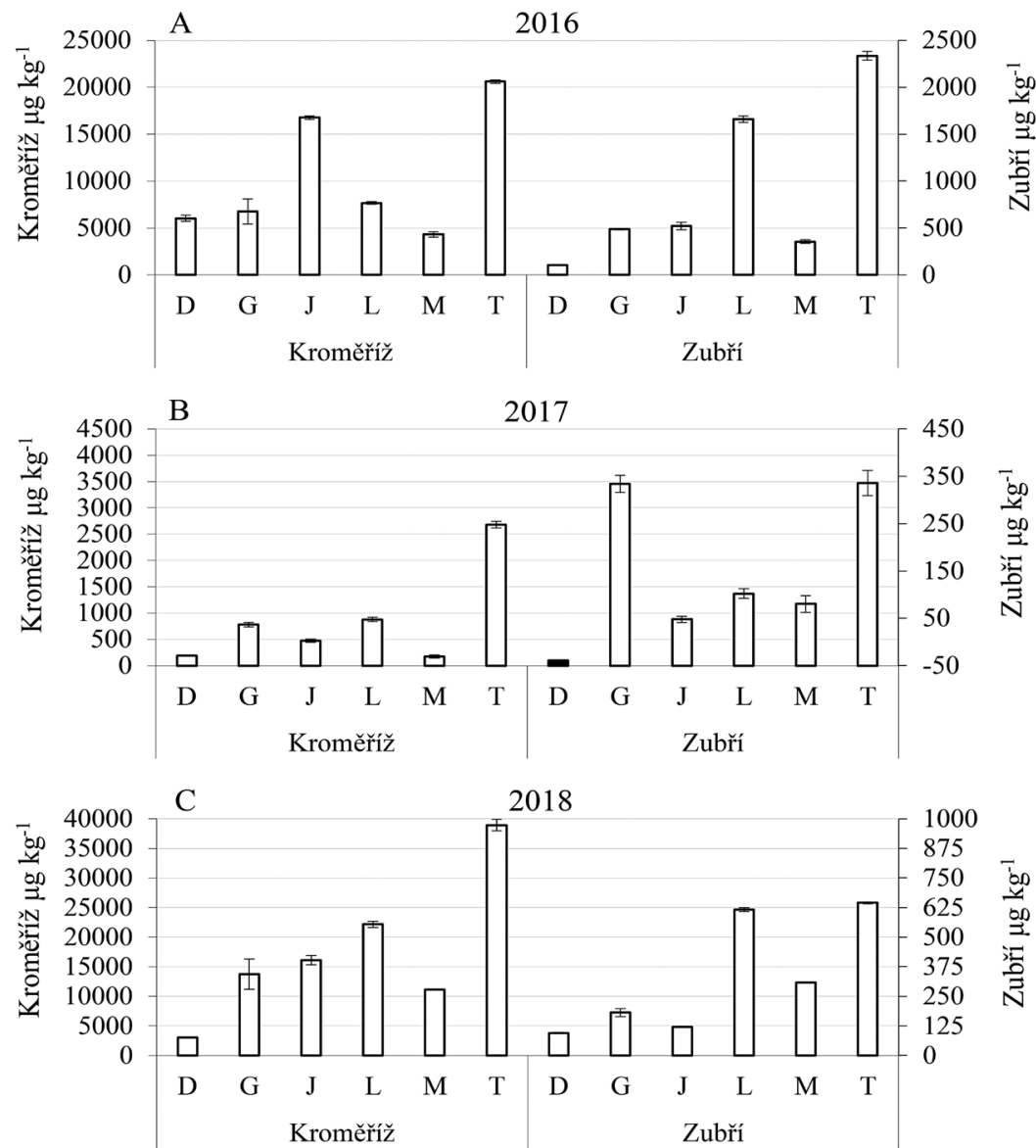

Note. Black bar is bellow limit of quantification (LOQ); because of different DON levels at locations, a scale of y axis is variable and specific for individual harvest year and location, in order to show proportions between cultivars; D - 'Dagmar', G - 'Genius', J - 'Julie', L - 'Lear', M - 'Matchball', T - 'Tobak'.

Figure 2. Deoxynivalenol (DON) content in six winter wheat cultivars grown at two locations (Kroměříž and Zubří) under Fusarium culmorum infection in the harvest years 2016-2018

at Zubří as a consequence of infection. At Kroměříž, sedimentation index of 'Julie' was reduced after infection the most of all cultivars (by 25\%), sedimentation index of 'Genius' - by $20 \%$.

\section{Conclusions}

1. The response of winter wheat grain characteristics to Fusarium culmorum infection was largely influenced by both genotype and environment.

2. There were significant differences in deoxynivalenol (DON) content between the wheat cultivars, in descending order as follows: 'Tobak' > 'Lear'> 'Genius' > 'Julie' > 'Matchball' > 'Dagmar'.

3. Gluten index and test weight proved to be grain characteristics that were most markedly affected by $F$. culmorum infection. Significant reduction was observed also for grain yield, thousand kernel weight (TKW), sedimentation index and falling number, while a significant increase was determined for crude protein content.

4. Changes in gluten index, test weight, TKW and yield were found only at the location with DON content higher than $3000 \mu \mathrm{g} \mathrm{kg}^{-1}$, whereas the changes in some other grain characteristics, mainly in sedimentation index, were observed in certain cultivars even for DON values below $500 \mu \mathrm{g} \mathrm{kg}^{-1}$.
5. Sedimentation index was the parameter the most subjected to interaction between cultivar and F. culmorum infection, the decrease was apparent mainly for the wheat cultivars with elite (E)-quality.

\section{Acknowledgements}

The research was funded by the Czech Ministry of Agriculture, project No. QJ1510204 and institutional support No. MZE- RO1118.

Received 03012019 Accepted 02012020

\section{References}

1. Becher R., Miedaner T., Wirsel S. G. R. 2013. Biology, diversity, and management of FHB-causing Fusarium species in small-grain cereals. The Mycota XI. Agricultural Applications ( $2^{\text {nd }}$ ed.). Chapter 8, p. 199-241. https://doi.org/10.1007/978-3-642-36821-9_8

2. Bilska K., Jurczak S., Kulik T., Ropelewska E., Olszewski J., Źelechowski M., Zapotoczny P. 2018. Species composition and trichothecene genotype profiling of Fusarium field isolates recovered from wheat in Poland. Toxins, 10 (8): 325. https://doi.org/10.3390/toxins10080325

3. Blandino M., Haidukowski M., Pascale M., Plizzari L., Scudellari D., Reyneri A. 2012. Integrated strategies for the control of Fusarium head blight and deoxynivalenol contamination in winter wheat. Field Crop Research, 133: 139-149. https://doi.org/10.1016/j.fcr.2012.04.004 
4. Boyacioglu D., Hettiarachchy N. S. 1995. Changes in some biochemical components of wheat grain that was infected with Fusarium graminearum. Journal of Cereal Science, 21 (1): 57-62. https://doi.org/10.1016/S0733-5210(95)80008-5

5. Dexter J. E., Clear R. M., Preston K. R. 1996. Fusarium head blight: effect on the milling and baking of some Canadian wheats. Cereal Chemistry, 73 (6): 695-701.

6. EC. 2006. Commission Regulation (EC) No 1881/2006 of 19 December 2006 setting maximum levels for certain contaminants in foodstuffs. Official Journal of the European Union, p. L 364/5.

7. Eggert K., Wieser H., Pawelzik E. 2010. The influence of Fusarium infection and growing location on the quantitative protein composition of (part I) emmer (Triticum dicoccum). European Food Research and Technology, 230 (6): 837-847. https://doi.org/10.1007/s00217-010-1229-3

8. Eggert K., Rawel H. M., Pawelzik E. 2011. In vitro degradation of wheat gluten fractions by Fusarium graminearum proteases. European Food Research and Technology, 233: 697-705. https://doi.org/10.1007/s00217-011-1566-x

9. EFSA. 2013. Deoxynivalenol in food and feed: occurrence and exposure: scientific report. European Food Safety Authority Journal, 11 (10): 3379 (56 p.). https://doi.org/10.2903/j.efsa.2013.3379

10. Häller Gärtner B., Munich M., Kleijer G., Mascher F. 2008. Characterisation of kernel resistance against Fusarium infection in spring wheat by baking quality and mycotoxin assessments. European Journal of Plant Pathology, 120 (1): 61-68. https://doi.org/10.1007/s10658-007-9198-5

11. Horáková V., Dvořáčková O. 2017. Seznam doporučených odrůd. Přehled odrůd. Central Institute for Supervising and Testing in Agriculture, 190 p. (in Czech).

12. Horvat D., Spanic V., Dvojkovic K., Simic G., Magdic D., Nevistic A. 2015. The influence of Fusarium infection on wheat (Triticum aestivum L.) proteins distribution and baking quality. Cereal Research Communications, 43 (1): 61-71.

https://doi.org/10.1556/CRC.2014.0023

13. Kreuzberger M., Limsuwan S., Eggert K., Karlovsky P., Pawelzik E. 2015. Impact of Fusarium spp. infection of bread wheat (Triticum aestivum L.) on composition and quality of flour in association with EU maximum level for deoxynivalenol. Journal of Applied Botany and Food Quality, 88: 177-185.

14. Martin C., Schöneberg T., Vogelgsang S., Vincenti J., Bertossa M., Mauch-Mani B., Mascher F., 2017. Factors of wheat grain resistance to Fusarium head blight. Phytopathologia Mediterranea, 56 (1): 154-166.

15. McMullen M., Bergstrom G., De Wolf E., Dill-Macky R., Hershman D., Shaner G., Van Sanford D. 2012. A unified effort to fight an enemy of wheat and barley: Fusarium head blight. Plant Disease, 96 (12): 1712-1728. https://doi.org/10.1094/PDIS-03-12-0291-FE

16. Mesterházy Á., Bartók T., Kászonyi G., Varga M., Tóth B., Varga J. 2005. Common resistance to different Fusarium spp. causing Fusarium head blight in wheat. European Journal of Plant Pathology, 112 (3): 267-281. https://doi.org/10.1007/s10658-005-2853-9

17. Mesterházy Á., Lehoczki-Krsjak S., Varga M., SzabóHevér Á., Tóth B., Lemmens M. 2015. Breeding for FHB resistance via Fusarium damaged kernels and deoxynivalenol accumulation as well as inoculation methods in winter wheat. Agricultural Sciences, 6: 970 1002. https://doi.org/10.4236/as.2015.69094
18. Miedaner T., Gwiazdowska D., Waśkiewicz A. 2017. Editorial: management of Fusarium species and their mycotoxins in cereal food and feed. Frontiers in Microbiology, 8: 1543.

https://doi.org/10.3389/fmicb.2017.01543

19. Papouškova L., Capouchova I., Kostelanska M., Škerikova A., Prokinova E., Hajšlova J., Salava J., Famera O. 2011. Changes in baking quality of winter wheat with different intensity of Fusarium spp. contamination detected by means of new rheological system Mixolab. Czech Journal of Food Sciences, 29 (4): 420-429. https://doi.org/10.17221/426/2010-CJFS

20. Pekkarinen A., Mannonen L., Jones B. L., NikuPaavola M. L. 2000. Production of proteases by Fusarium species grown on barley grains and in media containing cereal proteins. Journal of Cereal Science, 31 (3): 253-261. https://doi.org/10.1006/jcrs.2000.0305

21. Salgado J. D., Madden L. V., Paul P. A. 2015. Quantifying the effects of Fusarium head blight on grain yield and test weight in soft red winter wheat. Phytopathology, 105 (3): 295-306.

https://doi.org/10.1094/PHYTO-08-14-0215-R

22. Schmidt M., Horstmann S., De Colli L., Danaher M., Speer K., Zannini E., Arendt E. K. 2016. Impact of fungal contamination of wheat on grain quality criteria. Journal of Cereal Science, 69: 95-103.

https://doi.org/10.1016/j.jcs.2016.02.010

23. Siuda R., Grabowski A., Lenc L., Ralcewicz M., SpychajFabisiak E. 2010. Influence of the degree of fusariosis on technological traits of wheat grain. International Journal of Food Science and Technology, 45 (12): 2596-2604. https://doi.org/10.1111/j.1365-2621.2010.02438.x

24. Spanic V., Viljevac Vuletic M., Drezner G., Zdunic Z., Horvat D. 2017. Performance indices in wheat chlorophyll $a$ fluorescence and protein quality influenced by FHB. Pathogens, 6 (4): 59. https://doi.org/10.3390/pathogens6040059

25. Steiner B., Buerstmayr M., Michel S., Schweiger W., Lemmens M., Buerstmayr H. 2017. Breeding strategies and advances in line selection for Fusarium head blight resistance in wheat. Tropical Plant Pathology, 42 (3): 165-174. https://doi.org/10.1007/s40858-017-0127-7

26. Trümper C., Paffenholz K., Smit I., Kössler P., Karlovsky P., Braun H. P., Pawelzik E. 2015. Identification of differently regulated proteins after Fusarium graminearum infection of emmer (Triticum dicoccum) at several grain ripening stages. Food Technology and Biotechnology, 53 (3): 261268. https://doi.org/10.17113/ftb.53.03.15.3838

27. Wang J.H., Wieser H., PawelzikE., Weinert J., Keutgen A. J., Wolf G. A. 2005. Impact of the fungal protease produced by Fusarium culmorum on the protein quality and breadmaking properties of winter wheat. European Food Research and Technology, 220 (5-6): 552-559. https://doi.org/10.1007/s00217-004-1112-1

28. Wang J. H., Pawelzik E., Weinert J., Zhao Q., Wolf G. A. 2008. Factors influencing falling number in winter wheat. European Food Research and Technology, 226 (6): 1365-1371. https://doi.org/10.1007/s00217-007-0666-0 
ISSN 1392-3196 / e-ISSN 2335-8947

Zemdirbyste-Agriculture, vol. 107, No. 2 (2020), p. 113-122

DOI 10.13080/z-a.2020.107.015

\title{
Fusarium culmorum įtaka žieminiụ kviečių grūdų derliui ir savybėms
}

\author{
I. Polišenská ${ }^{1}$, K. Vaculová ${ }^{1}$, O. Jirsa ${ }^{1}$, I. Sedláčková ${ }^{1}, J_{\text {. Frydrych }}^{2}$ \\ ${ }^{1}$ UAB Agrotest Fyto, Čekijos Respublika \\ ${ }^{2}$ UAB OSEVA plètra ir tyrimai, Čekijos Respublika
}

\section{Santrauka}

Tirtas žieminio kviečio (Triticum aestivum L.) šešių veislių, besiskiriančių kepimo savybėmis, atsakas ị Fusarium culmorum infekciją. Trejus metus kviečiuose, augintuose lauko eksperimentuose, įrengtuose dviejose vietovėse, buvo tirta mikotoksino deoksinivalenolio (DON) kiekis, grūdų derlius ir savybès: natūrinis svoris, 1000 grūdų masè, kritimo skaičius, žalių baltymų kiekis, sedimentacijos indeksas, šlapiojo glitimo kiekis ir glitimo indeksas. Nustatyti esminiai DON kiekio skirtumai tarp tyrimo vietovių, derliaus metų ir veislių. Eksperimento duomenimis, F. culmorum infekcija turejo ịtakos visiems tirtiems kintamiesiems, išskyrus šlapiajji glitimą; daugeliu atvejų buvo nustatyta esminė infekcijos sąveika su kitais veiksniais.

Tyrimo rezultatai patvirtino daugialypę kviečių varpų fuzariozès kilmę ir parodè, kad, nors šiuo metu nèra šiai ligai visiškai atsparių žieminių kviečių veislių, tačiau išryškèjo dideli tirtų veislių atsparumo skirtumai. Dẻl nevienalytės varpų fuzariozès kilmès parenkant apsaugos produktus reikia atsižvelgti ị daugiau veiksnių; vienas iš jų - atsparesnių veislių parinkimas.

Reikšminiai žodžiai: grūdų kokybė, mikotoksinai, Triticum aestivum, varpų fuzariozè, veislè. 